\title{
Stage I Penile Cancer AJCC v6
}

National Cancer Institute

\section{Source}

National Cancer Institute. Stage I Penile Cancer A/CC v6. NCI Thesaurus. Code C7867.

Stage I includes: (T1, N0, M0). T1: Tumor invades subepithelial connective tissue. N0: No regional lymph node metastasis. M0: No distant metastasis. (AJCC 6th ed.) - 2003 